\title{
KUALITAS MANGGA LOMBOK UTARA PERLU DISESUAIKAN DENGAN PERMINTAAN PASAR UNTUK MEMPEROLEH NILAI YANG LEBIH TINGGI
}

\section{The Quality of North Lombok Mango Needs to be Adjusted to the Demand of the Market to Get a Higher Value}

\author{
Taslim Sjah ${ }^{1,3,{ }^{*}}$, Zainuri ${ }^{2}$ \\ ${ }^{1}$ Program Studi Agribsinis, Fakultas Pertanian, Universitas Mataram, ${ }^{2} I l m u$ dan Teknologi \\ Pangan, Fakultas Teknologi Pangan dan Agro Industri, Universitas Mataram, ${ }^{3}$ Program Studi \\ Pengelolaan Sumberdaya Lahan Kering, Program Pascasarjana, Universitas Mataram, \\ Jalan Majapahit Nomor 62 Kota Mataram Provinsi NTB, 83125 \\ *Alamat korespondensi: taslim.sjah@unram.ac.id
}

(Tanggal Submission: 4 Mei 2020, Tanggal Accepted: 30 Agustus 2020)

\begin{abstract}
ABSTRAK
Hasil penelitian menunjukkan bahwa kualitas mangga yang diminta oleh pasar, baik pasar lokal, nasional, dan internasional, berbeda dengan kualitas mangga yang dihasilkan oleh petani mangga dan yang dijual oleh pedagang buah mangga. Kegiatan pengabdian ini bertujuan untuk melakukan penyesuaian kualitas mangga dengan permintaan pasar, sehingga dapat menciptakan transaksi yang menguntungkan pihak penjual (produsen dan pedagang) dan pihak pembeli (pedagang dan konsumen) serta pihak terkait lainnya. Kegiatan pengabdian kepada masyarakat ini dilakukan penyuluhan dengan metode ceramah, praktik, dan diskusi tentang hal-hal yang terkait dengan mutu mangga guna memenuhi permintaan pedagang dan konsumen mangga. Untuk mencapai mutu mangga yang baik maka penanganan mangga dilakukan pada semua tahapan yang berpengaruh terhadap kualitas buah mangga, sejak tahapan produksi, pemeliharaan tanaman, panen, pasca panen, transportasi dan pemasaran buah mangga. Evaluasi terhadap kegiatan menunjukkan hasil positif berupa peningkatan pengetahuan dan motivasi untuk mengubah keadaan dalam agribisnis mangga dengan fokus untuk penyesuaian kualitas atau karakteristik mangga yang diproduksi terhadap mangga yang dikonsumsi.
\end{abstract}

Kata Kunci: Agribisnis; Mangga; peningkatan Kualitas produk;

\section{PENDAHULUAN}

Beberapa hasil penelitian menunjukkan bahwa ada perbedaan antara buah mangga yang diminta oleh pembeli (termasuk konsumen dan pedagang) dan buah mangga yang disediakan atau ditawarkan oleh produsen dan pedagang (Zainuri \& Sjah, 2018). Ketidaksesuaian antara permintaan dan penawaran ini menyebabkan salah satu atau kedua pihak menjadi tidak puas (Casavant, Infanger, \& Bridges, 1999; Cramer, Jensen, \& Southgate, 1997; Seitz, Nelson, \& 
Halcrow, 2002), sehingga disini tampak jelas adanya masalah. Produsen atau penjual tidak puas terutama karena produknya tidak habis terjual. Konsumen atau pembeli juga tidak puas terutama karena tidak memperoleh barang dengan kualitas yang diinginkan, sehingga merasa ada semacam kesia-siaan dengan korbanan (yaitu uang pembelian barang) yang dikeluarkan (Ganeshkumar, Pachayappan, \& Madanmohan, 2017; Koufteros \& Lu, 2017; Vorst, Silva, \& Trienekens, 2007).

Salah satu kelompok produsen mangga di Kabupaten Lombok Utara adalah Kelompok Pengepul Desa Gumantar, Kecamatan Kayangan, Kabupaten Lombok Utara. Kelompok ini melakukan perdagangan hasil bumi sesuai dengan hasil bumi yang diproduksi atau yang tersedia pada waktu (bulan) itu. Termasuk dalam hasil bumi yang diperdagangkan adalah mangga, baik mangga yang diproduksi pada lahan usahatani milik sendiri maupun yang diproduksi dan dibeli dari lahan usahatani orang lain atau teman-teman mereka di desa mereka sendiri atau di desa-desa sekitarnya di Kabupaten Lombok Utara. Kelompok Pengepul Desa Gumantar melakukan usaha perdagangan mangga (dan hasil pertanian lainnya), sesuai dengan musim dari hasil pertanian yang ada pada waktu tersebut. Kelompok pengepul ini membeli buah mangga dari petani yang ada di Desa Gumantar atau desa-desa sekitar. Setelah itu kelompok ini menjual mangga ke pasar lokal (di Kecamatan Tanjung) atau ke Mataram dan sekitarnya serta ke luar Lombok, yaitu ke Pulau Jawa, termasuk ke Jakarta. Mangga yang dibeli dan selanjutnya dijual terdiri dari segala jenis (varietas) yang ada, dan segala kualitas yang ada. Tidak ada pemilahan atau kegiatan untuk melakukan sortasi buah, dan tidak ada pula upaya-upaya untuk memperbaiki kualitas buah mangga. Mangga yang ada dengan kualitas yang ada atau apa adanya dijual dengan menegosiasikan harga bagi buah mangga tersebut. Jadi, disini harga yang mengikuti kualitas, bukan kualitas yang diperlukan peningkatan untuk mencapai harga yang lebih tinggi.

Dari uraian tentang kelompok usaha yang menjadi mitra kegiatan pengabdian ini maka dapat disarikan beberapa kelemahan atau permasalahan yang dihadapi mitra kegiatan ini. Kelemahan yang paling menonjol adalah keterbatasan informasi kualitas mangga yang diinginkan konsumen (pasar) beserta harga yang belaku. Seringkali kelompok ini merasakan bahwa harga yang diterima seharusnya bisa lebih tinggi dari yang berlaku sekarang. Demikian pula sebaliknya, kalaupun informasi harga diketahui, kelompok usaha ini tidak memiliki produk (buah mangga) dengan kualitas yang sesuai dengan permintaan pasar. Kelemahan lainnya adalah kelompok ini mempunyai wilayah pemasaran yang terbatas, dan tidak menjangkau pusat-pusat permintaan mangga dengan harga yang lebih tinggi (Morey, 2009; Taslim Sjah, 2013).

Sementara itu, dari sisi lain diketahui bahwa permintaan mangga oleh berbagai konsumen mangga menghendaki kualitas yang berbeda-beda, seperti konsumen di supermarket menghendaki kualitas mangga yang lebih tinggi dan 'bersedia' membayar dengan harga yang lebih tinggi (Taslim Sjah, 2013; Zainuri \& Sjah, 2018). Demikian pula, di beberapa lokasi konsumen, terutama di luar negeri konsumen menginginkan kualitas yang lebih tinggi dan mampu serta bersedia membayar lebih mahal (Zainuri \& Sjah, 2018).

Tujuan tulisan ini adalah melaporkan kegiatan pengabdian kepada masyarakat tentang perlunya melakukan penyesuaian produk mangga antara yang dihasilkan dan dijual dengan produk mangga yang diinginkan oleh konsumen, yang dengan kesesuaian tersebut maka manfaat yang diperoleh menjadi lebih besar, tidak hanya bagi produsen mangga tetapi juga pedagang dan konsumen mangga. Kepuasan konsumen buah mangga dari penyediaan mangga yang sesuai oleh produsen dan konsumen menyebabkan konsumen bersedia membayar buah mangga 
tersebut kepada pedagang dan produsen dengan harga yang lebih tinggi, sehingga memberi manfaat lebih besar bagi produsen dan memberi kepuasan lebih tinggi bagi konsumen.

\section{METODE PELAKSANAAN}

Sesuai dengan permasalahan yang dihadapi mitra, seperti yang telah dipaparkan sebelumnya, pada dasarnya masalah mitra dapat dikelompokkan menjadi 3 (tiga) masalah pokok, yaitu dalam aspek produksi, manajemen usaha, dan pemasaran produk. Dalam ketiga aspek tersebut masih terdapat kelemahan atau hal-hal yang perlu diperbaiki atau ditingkatkan. Untuk memberikan solusi terhadap masalah-masalah mitra tersebut maka kegiatan ini sangat penting untuk dilakukan.

Kegiatan pemberdayaan masyarakat ini menggunakan metode partisipatif, artinya dalam kegiatan ini masyarakat atau mitra dilibatkan dalam kegiatan perencanaan program (dimulai dengan idetifikasi masalah mitra secara bersamasama antara mitra dan tim pelaksana pengabdian ini), pelaksanaan program dan evaluasi terhadap pelaksanaan program. Dengan cara seperti ini, maka diharapkan masyarakat melakukan implementasi program berdasarkan pada kebutuhannya yang dirasakan pada awalnya atau distimulasi pada saat proses berlangsung (Guijt, 2000; Kemmis \& McTaggart, 2005; Pretty, Guijt, Scoones, \& Thompson, 1995). Dengan demikian, dalam implementasi program tersebut dilakukan melalui kegiatan-kegiatan pelatihan/demonstrasi, diskusi, praktik terhadap materi yang disampaikan, sehingga diperoleh tidak hanya pengetahuan tetapi juga keterampilan, yang merupakan aset penting perkembangan bisnis (dan juga kehidupan lainnya) lebih lanjut. Materi pelatihan kegiatan disampaikan langsung oleh tim pelaksana dan beberapa narasumber dalam bidang terkait dengan kegiatan pemberdayaan masyarakat ini.

Metode yang digunakan dalam pelatihan ini adalah metode ceramah dan diskusi. Ceramah disertai dengan peragaan untuk memfasilitasi pemahaman peserta penyuluhan. Pertanyaan diajukan oleh para peserta dan tim penyuluh menjawab pertanyaan secara bergiliran sesuai dengan keahlian atau materi yang disampaikan. Kadang-kadang tim pelaksana juga bertanya kepada peserta tentang pengalaman dan teknikteknik yang mereka praktikkan. Hasil-hasil ini kami gunakan untuk perbaikan dalam kegiatan-kegiatan selanjutnya, terkait dengan bisnis mangga

Tim pelaksana kegiatan pengabdian ini mengevaluasi efektivitas pelaksanaan kegiatan dan dampaknya dalam aspek-aspek permasalahan mitra, yaitu aspek produksi, manajemen, dan pemasaran produk. Hasil evaluasi ini tidak hanya untuk diterapkan pada periode kegiatan di waktu (tahun) mendatang tetapi juga diterapkan dalam kegiatan tahun berjalan, yaitu selama monitoring lanjutan, yaitu melakukan bimbingan untuk perbaikan terhadap aspek-aspek atau hal-hal yang dinilai lemah atau kurang sesuai dengan harapan. Langkah- langkah ini juga merupakan bimbingan dari tim pelaksana kegiatan bagi pelaku usaha untuk melakukan evaluasi terhadap masalah atau keadaan yang dihadapi sendiri. Dengan cara demikian, tim pelaksana sudah menyiapkan pelaku usaha dalam melakukan usahanya secara berhasil dan terus dapat mengevaluasi perkembangan usahanya, sehingga usahanya semakin berkembang dan tidak berhenti ketika kegiatan ini tidak dibina oleh tim pelaksana. Dengan kegiatan ini maka pelaku usaha diharapkan sudah dapat mandiri, tidak lagi bergantung kepada bantuan teknis dan manajemen dari luar. Hasil seperti demikian merupakan hasil yang diharapkan dalam pemberdayaan masyarakat, yaitu membuat masyarakat berdaya dalam kehidupan mereka (lihat misalnya Reza, 2003; Sastry \& Manikandan, 2002; Sumodiningrat, 1999).

\section{HASIL DAN PEMBAHASAN}

\section{Realisasi kegiatan}

Setelah adanya informasi tentang persetujuan kegiatan ini maka tim pelaksana 
melakukan penjajakan tentang rencana pelaksanaan sesi informasi (penyuluhan) kepada pelaku agaribisnis (petani dan pedagang) mangga dari kelompok mitra, yang telah menyetujui kegiatan ini pada saat pengusulannya. Tim pelaksana berkunjung ke lokasi mitra dan berdiskusi dengan mitra.

Kegiatan kunjungan dan penyuluhan dilakukan pada tanggal 24 Agustus 2019, 31 Agustus 2019, dan 7 September 2019. Kegiatan ini dilaksanakan untuk mencapai tujuan yang telah disebutkan pada bagian tujuan kegiatan ini. Materi yang diberikan untuk penambahan pengetahuan dan/atau keterampilan adalah sesuai dengan tujuan yang telah ditetapkan. Materi yang diberikan menyangkut antara lain tentang kualitas mangga yang diinginkan konsumen (Zainuri \& Sjah, 2018; Zainuri, Sjah, Nurrachman, \& Ayu, 2019), manajemen usaha (Beierlein, Schneeberger, \& Osburn, 1986; Downey \& Erickson, 1987; Taslim Sjah, Rosmilawati, \& Zainuri, 2012; T. Sjah \& Zainuri, 2020), teori permintaan (Penson, Capps, \& Rosson, 2002; Seitz et al., 2002; Taslim Sjah, 2010), teori penawaran (Penson et al., 2002; Seitz et al., 2002; Taslim Sjah, 2010), dan pemasaran produk (Kotler \& Armstrong, 2011; Taslim Sjah, 2010; Smith, 2002; Stanton, Etzel, \& Walker, 2000). Materi disampaikan secara bertahap dan sebagian materi ada yang disampaikan berulang, sesuai dengan permintaan atau pertanyaan dari peserta penyuluhan. Beberapa photo kegiatan dan photo mangga dengan beberapa kualitas, dapat dilihat di bawah ini.

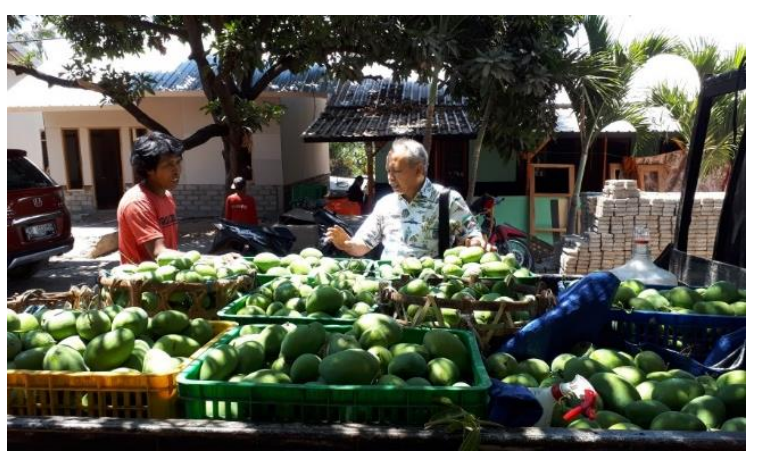

Foto 1. Penyuluhan tentang kualitas dan pengiriman mangga

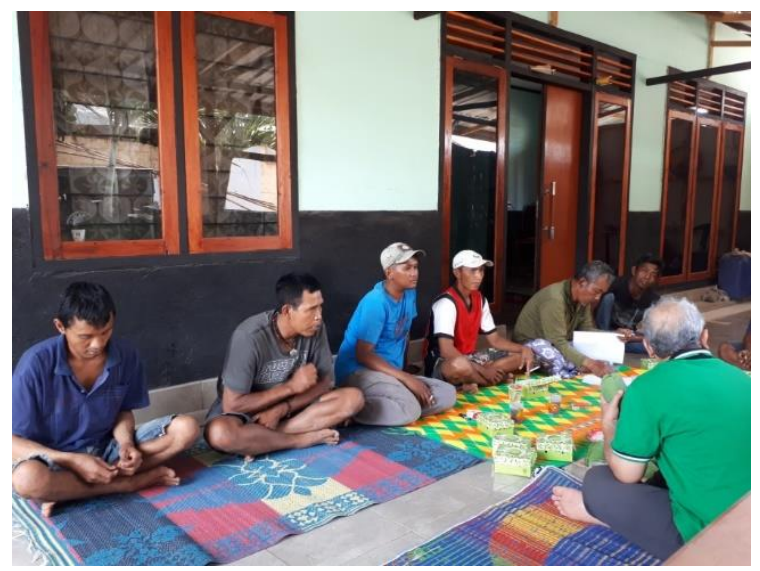

Foto 2. Penyuluhan tentang berbagai aspek agribisnis mangga

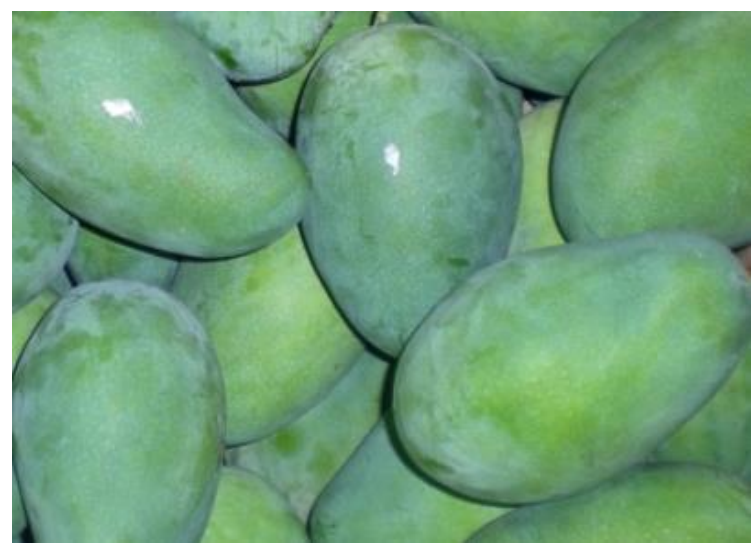

Foto 3. Buah mangga berkualitas 'super' 


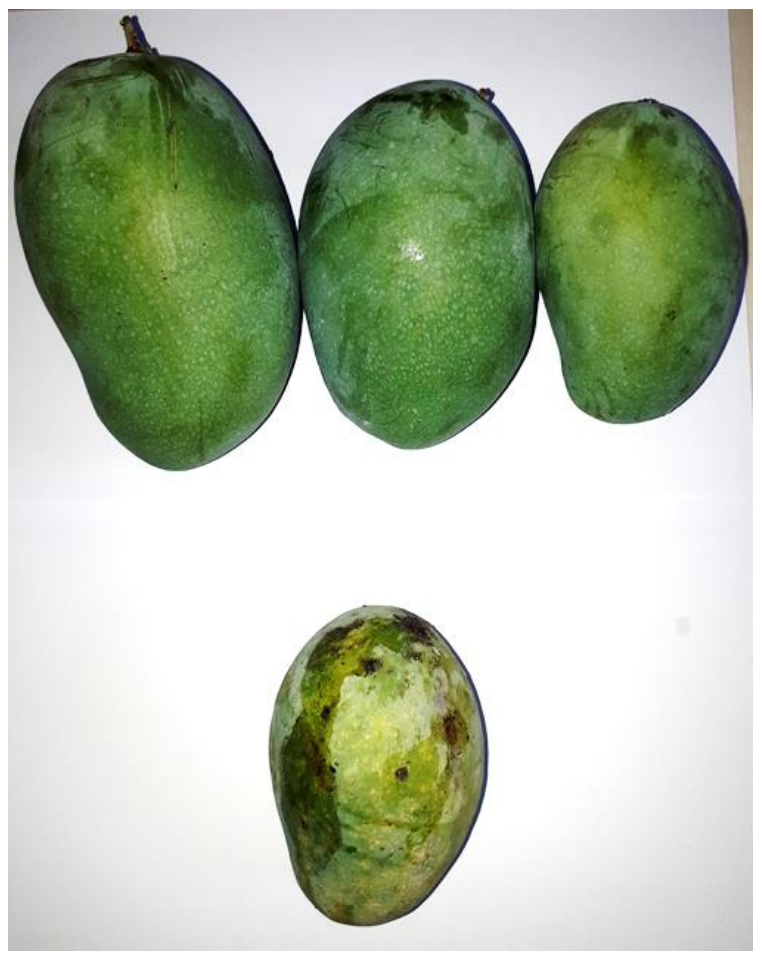

Foto 4. Buah mangga berkualitas 1, 2, 3, dan buah sisa (berurutan dari paling kiri atas)

\section{Evaluasi kegiatan}

Kegiatan telah dilaksanakan sesuai dengan rencana, termasuk tentang materi, waktu, dan hasil yang diharapkan. Dengan kata lain, pelaksanaan kegiatan ini dinilai efektif. Efektivitas hasil diperkuat dengan komunikasi yang baik, interaktif, dan berkelanjutan selama pelatihan dan setelah selesainya kegiatan penyuluhan ini. Peserta pelatihan menanyakan banyak hal kepada narasumber dan mereka antusias. Tim penyuluh juga sangat bersimpati terhadap kesulitan yang sedang dialami oleh peserta penyuluhan, yang sebagian masih merasakan kesedihan dan shock karena kejadian gempa yang berulang-ulng di lokasi tersebut dan dengan skala gempa yang relatif besar dan telah berdampak merusak bangunan, bahkan lahan. Beberapa peserta menyatakan bahwa mereka akan memanfaatkan materi pelatihan untuk dipraktikkan. Peserta juga berhasrat untuk mendapatkan pelatihan tambahan dan bimbingan lanjutan dalam beberapa aspek terkait. Mereka juga menyampaikan keinginan untuk dikunjungi kembali di waktu-waktu mendatang.

\section{Faktor pendukung dan penghambat kegiatan}

Ada cukup banyak faktor yang mendukung pelaksanaan kegiatan penyuluhan ini dan pelaksanaan hasil-hasilnya. Termasuk sebagai faktor pendukung ini adalah antusiasme dan kesadaran peserta untuk meningkatkan kondisi perekonomian mereka, terutama karena terdampak negatif dari gempa yang terjadi. Faktor ini menggerakkan mereka (petani dan keluarga) untuk mengikuti kegiatan penyuluhan dan kemudian mengaplikasikan dengan kaidah (agri) bisnis.

Selain itu, masyarakat desa setempat merupakan masyarakat yang suka bekerjasama untuk kepentingan bersama (bergotong royong merupakan tradisi yang rajin dipraktikkan). Kondisi ini merupakan modal untuk maju bersama dalam suatu bisnis, termasuk agribisnis yang bisa dikelola secara kelompok, ataupun secara individual.

Sebaliknya ada juga faktor penghambat seperti jarak lokasi yang cukup jauh sehingga agak menyulitkan untuk bisa sering-sering bertemu dengan anggota kelompok masyarakat lainnya. Demikian juga dengan jauhnya desa ini dengan pusat-pusat ekonomi sehingga untuk pemasaran produk akan memerlukan transportasi yang jauh dan biaya yang relatif tinggi. Di atas semua hambatan yang telah disebutkan juga ada kondisi yang belum tenang dan belum nyaman dalam kehidupan mereka. Oleh karena itu, faktor-faktor yang menghambat ini perlu dipikirkan pemecahannya, antara lain dengan membangun atau memperbaiki kondisi jalan dan perumahan penduduk. Banyak pihak perlu bekerjasama untuk mengatasi masalah ini. 


\section{KESIMPULAN DAN SARAN}

\section{Kesimpulan}

Evaluasi terhadap kegiatan menunjukkan hasil positif berupa peningkatan pengetahuan dan keterampilan dalam agribisnis mangga sejak dari tahap produksi, panen, pascapanen, dan pemasaran produk atau buah mangga. Sebagian peserta juga menyatakan bahwa mereka akan menerapkan pengetahuan dn keterampilan yang diperoleh. Namun hasil ini mungkin baru dapat terlihat pada tahun berikutnya, karena secara alamiah produksi mangga normalnya berlangsung sekali setahun.

\section{Saran}

Kegiatan pelatihan ini perlu dilanjutkan dengan pembimbingan dari waktu ke waktu. Ini karena materi yang telah disampaikan hanya bisa hanya bisa diterapkan secara bertahap dan juga proses produksi mangga dan kelanjutannya berlangsung secara bertahap. Juga perkembangan pengetahuan dan teknologi yang terus berubah, harus diikuti dengan penyesuaian yang terus menerus dari waktu ke waktu, agar kehidupan usaha tetap bisa berlangsung.

\section{UCAPAN TERIMA KASIH}

Terima kasih dsampaikan kepada Kementerian Riset, Teknologi, dan Pendidikan Tinggi, yang telah membiayai kegiatan pengabdian kepada masyaakat ini. Juga disampaikan penghargaan kepada semua pihak yang telah membantu terlaksananya kegiatan ini melalui berbagai bentuk, termasuk fasilitasi, pemberian informasi, penyemangatan, dan semacamnya. Terima kasih untuk semuanya.

\section{DAFTAR PUSTAKA}

Beierlein, J. G., Schneeberger, K. C., \& Osburn, D. D. (1986). Principles of Agribusiness Management. Englewood Cliffs, New Jersey: Prentice-Hall.
Casavant, K. L., Infanger, C. L., \& Bridges, D. E. (1999). Agricultural economics and management. Upper Saddle River, New Jersey: Prentice Hall.

Cramer, G. L., Jensen, C. W., \& Southgate, D. D. J. (1997). Agricultural economics and agribusiness (7 ed.). New York: John Wiley \& Sons, Inc.

Downey, W. D., \& Erickson, S. P. (1987). Agribusiness Management. New York: McGraw-Hill.

Ganeshkumar, C., Pachayappan, M., \& Madanmohan, G. (2017). Agri-food Supply Chain Management. Intelligent Information Management, 9, 68-96. Retrieved from http://www.scirp.org/journal/iim

Guijt, I. (2000). Methodological issues in participatory monitoring and evaluation. In M. Estrella, J. Blauert, D. Campilan, J. Gaventa, \& R. Ricafort (Eds.), Learning from change: Issues and experiences in participatory monitoring and evaluation (pp. 201-216). London \& Ottawa: ITPL \& IDRC.

Kemmis, S., \& McTaggart, R. (2005). Participatory action research: Communicative action and the public sphere. In N. K. Denzin \& Y. S. Lincoln (Eds.), The Sage Hanbook of Qualitative Research ( ${ }^{\text {rd }}$ ed., pp. 559-604). Thousand Oaks, California: Sage Publications.

Kotler, P., \& Armstrong, G. (2011). Principles of Marketing (14 ed.). New Jersey: Pearson Prentice Hall.

Koufteros, X., \& Lu, G. (2017). Food Supply Chain Safety and Security: A Concern of Global Importance. Journal of Marketing Channels, 24(3-4), 111-114. doi:10.1080/1046669X.2017.1393227

Morey, P. (2009). Review of Indonesian Fresh Fruit and Vegetable Supply Chain. Ujung Pandang: Internatioanl Finance Cooperation.

Penson, J. B. J., Capps, O. J., \& Rosson, C. P. I. (2002). Introduction to agricultural economics (3rd ed.). Upper Saddle River, New Jersey: Prentice Hall.

Pretty, J. N., Guijt, I., Scoones, I., \& Thompson, J. (1995). A trainer's guide for 
participatory learning and action. London: International Institute for Environment and Development.

Reza, M. H. (2003). When culture trumps ideology: Microenterprise and the empowerment of women in Bangladesh. Canadian Journal of Development Studies-Revue Canadienne $D$ Etudes Du Developpement, 24(3), 439-459. Retrieved from <Go to $|S|>: / / 000187181200006$

Sastry, R. K., \& Manikandan, P. (2002). Empowerment of women on an agricultural research farm in India: a success story. Outlook on Agriculture, 31(4), 253-258. Retrieved from <Go to ISI>://000180182700005

Seitz, W. D., Nelson, G. C., \& Halcrow, H. G. (2002). Economics of resources, agriculture, and food (2 ed.). New York: McGraw-Hill.

Sjah, T. (2010). Ekonomi Pertanian. Mataram: Mataram University Press.

Sjah, T. (2013). Profile of mango collectors in Nusa Tenggara Barat. Mataram: Faculty of Agriculture, University of Mataram.

Sjah, T., Rosmilawati, \& Zainuri. (2012). Rencana Bisnis: Untuk pengusaha kecil dan pemula dalam usaha pengolahan hasil pertanian. Mataram: Mataram University Press.
Sjah, T., \& Zainuri, Z. (2020). Agricultural Supply Chain and Food Security. In W. Leal Filho, A. Azul, L. Brandli, P. Özuyar, \& T. Wall (Eds.), Zero Hunger. Encyclopedia of the UN Sustainable Development Goals (pp. 1-10). Cham: Springer.

Smith, K. (2002). Marketing for small business. Milton: Wrightbook.

Stanton, W. J., Etzel, M. J., \& Walker, B. J. (2000). Fundamentals of Marketing. New York: McGraw-Hill.

Sumodiningrat, G. (1999). Pemberdayaan masyarakat dan jaring pengaman sosial (Community empowerment and social security net). Jakarta: Gramedia Pustaka Utama.

Vorst, J. G. A. J. v. d., Silva, C. A. d., \& Trienekens, J. H. (2007). Agro-industrial supply chain management: concepts and applications. Rome: FAO.

Zainuri, \& Sjah, T. (2018). Survei kualitas mangga dalam rantai pemasaran mangga. Mataram: Universitas Mataram.

Zainuri, Sjah, T., Nurrachman, \& Ayu, C. (2019). Mango off-season technology (MOST): Innovative, applicable, adaptive to climate change, and brings many positive impacts. Paper presented at the The 2nd International Conference On Bioscience, Biotechnology, And Biometrics 2019, Mataram. 